Article (refereed)

Dinsmore, Kerry J.; Skiba, Ute M.; Billett, Michael F.; Rees, Robert M.. 2009 Effect of water table on greenhouse gas emissions from peatland mesocosms. Plant and Soil, 318 (1-2). 229-242. 10.1007/s11104-0089832-9

(C) Springer Science + Business Media B.V. 2008

This version available at http://nora.nerc.ac.uk/5459/

NERC has developed NORA to enable users to access research outputs wholly or partially funded by NERC. Copyright and other rights for material on this site are retained by the authors and/or other rights owners. Users should read the terms and conditions of use of this material at http://nora.nerc.ac.uk/policies.html\#access

This document is the author's final manuscript version of the journal article, incorporating any revisions agreed during the peer review process. Some differences between this and the publisher's version remain. You are advised to consult the publisher's version if you wish to cite from this article.

www.springerlink.com 


\section{Effect of water table on greenhouse gas 2 emissions from peatland mesocosms}

3 Kerry J. Dinsmore ${ }^{1}$, Ute M. Skiba ${ }^{1}$, Michael F. Billett ${ }^{1}$, Robert M. Rees ${ }^{2}$

${ }^{1}$ Centre for Ecology and Hydrology, Bush Estate, Penicuik, UK, EH26 0QB

7 Phone: +44 (0) 1314458583

8 Fax: +44 (0) 1314453943

$9 \quad$ Email: kjdi@ceh.ac.uk

11 Peatland landscapes typically exhibit large variations in greenhouse gas (GHG) emissions due to

12 microtopographic and vegetation heterogeneity. As many peatland budgets are extrapolated from

13 small-scale chamber measurements it is important to both quantify and understand the processes

14 underlying this spatial variability. Here we carried out a mesocosm study which allowed a

15 comparison to be made between different microtopographic features and vegetation communities,

16 in response to conditions of both static and changing water table. Three mesocosm types

17 (hummocks + Juncus effusus, hummocks + Eriophorum vaginatum, and hollows dominated by

18 moss) were subjected to 2 water table treatments $(0-5 \mathrm{~cm}$ and $30-35 \mathrm{~cm}$ depth). Measurements

19 were made of soil-atmosphere GHG exchange, GHG concentration within the peat profile and soil

20 water solute concentrations. After 14 weeks the high water table group was drained and the low

21 water table group flooded. Measurement intensity was then increased to examine the immediate

22 response to change in water table position.

23 Mean $\mathrm{CO}_{2}, \mathrm{CH}_{4}$ and $\mathrm{N}_{2} \mathrm{O}$ exchange across all chambers was $39.8 \mu \mathrm{g} \mathrm{m}^{-2} \mathrm{~s}^{-1}, 54.7 \mu \mathrm{g} \mathrm{m}^{-2} \mathrm{~h}^{-1}$ and -

$242.9 \mu \mathrm{g} \mathrm{m}^{-2} \mathrm{~h}^{-1}$, respectively. Hence the GHG budget was dominated in this case by $\mathrm{CO}_{2}$ exchange.

$25 \mathrm{CO}_{2}$ and $\mathrm{N}_{2} \mathrm{O}$ emissions were highest in the low water table treatment group; $\mathrm{CH}_{4}$ emissions were

26 highest in the saturated mesocosms. We observed a strong interaction between mesocosm type and

27 water table for $\mathrm{CH}_{4}$ emissions. In contrast to many previous studies, we found that the presence of

28 aerenchyma-containing vegetation reduced $\mathrm{CH}_{4}$ emissions. A significant pulse in both $\mathrm{CH}_{4}$ and

$29 \mathrm{~N}_{2} \mathrm{O}$ emissions occurred within 1-2 days of switching the water table treatments. This pulsing

30 could potentially lead to significant underestimation of landscape annual GHG budgets when

31 widely spaced chamber measurements are upscaled.

32 Greenhouse gases; Water table; Vegetation; Microtopography; Peatland;

33 Mesocosm; 


\section{Introduction:}

2 Northern peatlands are estimated to contain 455 Gt of carbon (Gorham 1991),

3 representing approximately a third of the estimated total global soil carbon pool.

4 They are considered to be net sinks of $\mathrm{CO}_{2}$ and net sources of $\mathrm{CH}_{4}$ (Bartlett and

$5 \quad$ Harriss 1993; Gorham 1991; Huttunen et al. 2003), though annual and inter-annual

6 variation can be extremely high. Peatlands also represent an important source of

7 dissolved organic carbon to drainage waters (Urban et al. 1989; Billett et al. 2004;

8 Dawson et al. 2004). As soluble nitrogen is often limited, soil-atmosphere fluxes

9 of $\mathrm{N}_{2} \mathrm{O}$ tend to be small, although with a global warming potential of 298 (IPCC

10 2007) they can still contribute significantly to the total GHG budget. Some of the

11 primary consequences of climate change, including increased temperatures,

12 increased drought and increased frequency and intensity of rainfall events, are

13 likely to directly influence peatland ecosystems. This in addition to management

14 practices such as peatland drainage, means that it is becoming increasingly

15 important to accurately predict the biospheric feedbacks of peatlands to climate.

16 The main controls on soil carbon and nitrogen cycling in peatlands are a)

17 temperature, as it controls the rate of microbial activity; b) water table depth as it

18 determines the depth of the oxic/anoxic boundary and redox level within the soil;

19 and c) plant community composition and structure which influences the quantity

20 and quality of organic substrate available, and can alter the aerobic capacity of the

21 peat by transporting $\mathrm{O}_{2}$ to the rhizosphere (Bartlett and Harriss 1993; Dise et al.

22 1993; Ström et al. 2003; Whiting and Chanton 1996; Yavitt et al. 1997). In the

23 same way that certain plant species have the ability to transport $\mathrm{O}_{2}$ from the

24 atmosphere to the rhizosphere, they can provide a direct pathway for many GHGs

25 to the atmosphere, bypassing the aerobic peat horizon (Bartlett and Harriss 1993;

26 Minkkinen and Laine 2006). Such plant mediated transport has been demonstrated

27 to account for $>80 \%$ of $\mathrm{CH}_{4}$ emissions from rice paddies (Butterbach-Bahl et al.

28 1997; Yu et al. 1997).

29 The microtopographic pattern of elevated hummocks, wetter hollows and

30 submerged pools, typical of many peatlands, can cause significant variation in soil

31 environmental conditions (Nungesser 2003). Such differences are further

32 reinforced by the colonisation of distinct plant communities. As a result GHG 
1 production, emission and consumption within peatlands can vary considerably at

2 scales $<1 \mathrm{~m}^{2}$. Problems arise when gas exchange measurements, made using

3 chambers of usually $<0.5 \mathrm{~m}^{2}$, require up-scaling to catchment level.

4 The influence of water table depth on $\mathrm{CO}_{2}$ and $\mathrm{CH}_{4}$ soil-atmosphere exchange has

5 been studied repeatedly using flask experiments on disturbed peat (Blodau and

6 Moore 2003a; Öquist and Sundh 1998), measurements on relatively undisturbed

7 peat cores (Aerts and Ludwig 1997; Moore and Dalva 1993), and field studies

8 (Hargreaves and Fowler 1998; MacDonald et al. 1998). Only a small number of

9 controlled experiments have been carried out with the vegetation structure intact

10 (Blodau et al. 2004; Blodau and Moore 2003a). Fewer still have compared

11 different vegetation/microtopography types (though examples include: Updegraff

12 et al. 2001), despite studies showing that the influence of vegetation is species-

13 specific (Butterbach-Bahl et al. 1997; Ström et al. 2005). Such comparisons are

14 important as the relative coverage of each community type may be altered

15 following ecological succession resulting from long-term environmental change

16 (Strack et al. 2006; Weltzin et al. 2003). The general consensus from these studies

17 is that lowering the water table increases $\mathrm{C}$ mineralization and decreases $\mathrm{CH}_{4}$

18 emissions. Studies into the effects of water table depth on peatland $\mathrm{N}_{2} \mathrm{O}$ emissions

19 include those by Aerts and Ludwig (1997) and Regina et al. (1999); they conclude

20 that lowering the water table depth leads to a net increase in $\mathrm{N}_{2} \mathrm{O}$ emissions.

21 The aims of this study are: a) to compare the greenhouse gas budget (with

22 emphasis on $\mathrm{CH}_{4}$ and $\mathrm{N}_{2} \mathrm{O}$ ) and temperature response of peatland mesocosms

23 under high and low water table conditions; b) to quantify the immediate $\mathrm{CH}_{4}$ and

$24 \mathrm{~N}_{2} \mathrm{O}$ exchange response to a sudden changes in water table depth; and c) to assess

25 the influence of vegetation/microtopography on these responses.

\section{Materials and Methods:}

\section{Site Description}

28 Cores were collected from Auchencorth peatland (554ㄱ'34N; 3¹4’35W),

29 approximately $17 \mathrm{~km}$ south west of Edinburgh (Scotland). Mean annual

30 precipitation at the site (1995-2006) is $1016 \mathrm{~mm}$ (Coyle, unpublished data, 2008) 
with maximum and minimum monthly mean temperatures (1971-2000) of $19{ }^{\circ} \mathrm{C}$

2 in July and $0.7^{\circ} \mathrm{C}$ in January respectively (www.metoffice.gov.uk).

3 The catchment is a 335 ha grass dominated, lowland ombrotrophic peatland with

4 an elevation range of 249 to $300 \mathrm{~m}$ (Billett et al. 2004). The land-use is primarily

5 low intensity sheep grazing, though overgrown ditches are evidence of past

6 drainage. The vegetation is a patchy mix of coarse grasses and soft rush covering

7 a Sphagnum base layer. Calluna vulgaris is present in the south-west of the

8 catchment where drainage is better. The microtopography consists of a series of

9 hummocks and hollows. Hummocks are typically small ( 40 cm diameter, 30

$10 \mathrm{~cm}$ height) and dominated by either a mix of Deschamsia flexuosa and

11 Eriophorum vaginatum, or Juncus effusus. Hollows refer to the areas between

12 hummocks and are dominated by mosses (Sphagnum papillosa and Polytrichum

13 commune) and a thinner layer of grasses; hollows often become submerged after

14 periods of intense or sustained rainfall. Water table at the site generally fluctuates

15 between the peat surface and $20 \mathrm{~cm}$ depth, although during dry periods it is often

16 drawn down to $>35 \mathrm{~cm}$ (Coyle, unpublished data, 2008). The mean water

17 extractable DOC is $312 \pm 15.9$ (SE) $\mu g \mathrm{C} \mathrm{g}^{-1}$ dry soil and KCL extractable $\mathrm{NO}_{3}{ }^{-}$

18 and $\mathrm{NH}_{4}{ }^{+}$are $4.45 \pm 0.48$ (SE) and $21.8 \pm 1.85$ (SE) $\mu \mathrm{g} \mathrm{N} \mathrm{g}{ }^{-1}$ dry soil, respectively

19 (Dinsmore, unpublished data, 2008). Total N and S deposition at the site are 16.5

$20 \mathrm{~kg} \mathrm{~N} \mathrm{ha}^{-1} \mathrm{a}^{-1}$ and $6.9 \mathrm{~kg} \mathrm{~S} \mathrm{ha}^{-1} \mathrm{a}^{-1}$ respectively (Smith, personal communication, 21 2008).

22 To minimise variation in factors other than microtopography, the cores were all

23 collected within an area of approximately $10 \mathrm{~m}^{2}$. Peat depth at the sample site was

24 approximately $0.5 \mathrm{~m}$, overlaying a mineral subsoil. Peat core $\mathrm{pH}$ ranged from 3.8-

25 4.3, typical of the catchment as a whole which ranges from 3.6-4.6 (Dinsmore,

26 unpublished data). Mean bulk density was $0.12 \mathrm{~g} \mathrm{~cm}^{-3}$.

\section{Experimental Design}

28 Three distinct peatland topographic/vegetation features were identified as

29 comprising the majority of the field heterogeneity; hollows, hummocks dominated

30 by the rush Juncus effusus, and hummocks dominated by a mixture of grass and

31 sedge. Eight cores were collected from each ecotope in December 2006; 24 cores

32 in total. A $30 \mathrm{~cm}$ diameter, $50 \mathrm{~cm}$ long, stainless-steel, cylindrical corer was used 
1 to cut into the peat. The core was then dug out, cut to size and immediately

2 transferred to near-parallel sided buckets (30 cm diameter, $41 \mathrm{~cm}$ height) with as

3 little disturbance to the soil as possible. The following terminology will be used

4 henceforth in reference to the 3 different mesocosm types: hummock $+J$. effusus

5 (Juncus/Hummock), hummock + grass and sedge (Sedge/Hummock), hollow

6 (Hollow).

7 Dip wells, consisting of perforated pipes inserted into the soil and sealed at the top

8 with rubber bungs, were placed into each mesocosm. Deep and shallow soil

9 atmosphere wells were created by inserting water tight, gas permeable tubing

10 (Accurel $^{\odot}$, Gut et al. 1998) horizontally into the mesocosms at depths of $10 \mathrm{~cm}$

11 and $30 \mathrm{~cm}$ below the soil surface. The Accurel ${ }^{\odot}$ was sealed to gas tight tubing

12 (using Plasti Dip ${ }^{\circledR}$ ) which was then extended to the mesocosm surface for sample

13 collection (Fig. 1); the surface sampling port was closed to the atmosphere using a

14 3-way tap. Mesocosms were individually placed within larger buckets and the

15 space between filled with polystyrene chips to insulate and mimic field conditions

16 (Fig. 1). Each mesocosm was assigned to either a high or low water table group,

17 leading to a repeated measures factorial design. The mesocosms were arranged

18 using a randomised block design into 6 rows of 4 under a rain shelter, located

19 outside the Centre for Ecology and Hydrology Edinburgh, approximately $10 \mathrm{~km}$

20 from the Auchencorth Moss field site. Mesocosms were allowed to acclimatise in-

21 situ for 4 weeks before measurements began.

\section{Static water table treatment}

23 From core collection until the end of May 2007, water table depth was held

24 constant by daily inspection and manually refilling with rain water collected on-

25 site. The mean ion concentrations in rainwater $\left(\mathrm{mmol} \mathrm{m}^{-2}\right.$ week $\left.^{-1}\right)$, measured from

26 June to October 2006, were as follows: Sodium 0.56; Ammonium 0.26; Potassium

27 0.05; Calcium 0.37; Magnesium 0.13; Chloride 0.85; Nitrate 0.36; Sulphate 0.34

28 (Cape et al., pre-publication, 2008). Water table depth in the high and low water

29 table groups was held at 0-5 cm and 30-35 cm below the soil surface, respectively.

30 Weekly measurements of $\mathrm{CH}_{4}$ and $\mathrm{N}_{2} \mathrm{O}$ were made using static chambers. A clear

31 plastic lid was sealed to each mesocosm and air samples collected at time zero,

32 after 20 minutes and after 40 minutes. Soil air samples were collected weekly

33 from the gas permeable tubing, and water samples collected fortnightly from the 
1 dip wells. Soil temperature at $\sim 5 \mathrm{~cm}$ was measured at the same time as flux

2 measurements and soil atmosphere sampling. Total mesocosm net ecosystem

3 exchange (NEE) was measured using a static chamber connected to a PP-Systems

4 EGM-4 infrared gas analyser, which measures $\mathrm{CO}_{2}$ concentrations every 4

5 seconds. Measurements were made under 4 different light conditions produced

6 using full sunlight, 1 shade cloth, 2 shade cloths and a black out cloth and

7 combined to produce light response curves. Photosynthetically active radiation

8 (PAR) and temperature were measured inside the NEE chamber alongside $\mathrm{CO}_{2}$

9 concentration. Photosynthesis was calculated as total NEE minus the combined

10 plant and soil respiration (NEE under dark conditions).

\section{Rewetting/Draining}

12 At the end of May 2007 (after approximately 14 weeks of measurements), the 13 water table treatments were reversed. Drainage of the saturated mesocosms was

14 achieved using a siphon placed in the dip well; re-wetting of the drier mesocosms

15 was carried out by periodic watering over a 2 day period. Thereafter, $\mathrm{CH}_{4}$ and

$16 \mathrm{~N}_{2} \mathrm{O}$ fluxes were measured and solute samples collected daily for one week and

17 then every 2 days for a second week.

\section{Analytical methods}

19 Both chamber and soil atmosphere samples were analysed using a HP5890 Series

20 II gas chromatograph (detection limits: $\mathrm{CO}_{2}<199$ ppmv, $\mathrm{CH}_{4}<1.26 \mathrm{ppmv}, \mathrm{N}_{2} \mathrm{O}$

$21<0.2$ ppmv). Water samples were analysed for DOC and DIC on a Rosemount-

22 Dohrmann DC-80 total organic carbon analyser (detection range 0.1 to 4000

23 ppmv), using ultraviolet oxidation and sparging with $\mathrm{N}_{2}$ to remove acidified

24 inorganic carbon. $\mathrm{NO}_{3}{ }^{-}$and $\mathrm{NH}_{4}{ }^{+}$were analysed on a dual channel CHEMLAB

25 continuous flow colorimetric analyser (detection range $\mathrm{NH}_{4}{ }^{+}-\mathrm{N}$ : 0.25 to $3.0 \mathrm{ppmv}$;

$26 \mathrm{NO}_{3}{ }^{-} \mathrm{N}: 0.25$ to $\left.5.0 \mathrm{ppmv}\right)$.

\section{Statistical Analysis}

28 Repeated measures MANOVA was used when testing the significance of

29 mesocosm type and water table treatment on measured variables; an interaction

30 term was also included in the model specification. ANOVA was used when

31 considering mesocosm respiration, photosynthesis and NEE, with temperature as 
1 a covariate where appropriate. Quoted test results refer to Pillai’s test statistic

2 (Townend 2002) unless stated otherwise. Normality was assessed using the

3 Kolmogorov-Smirnov test (Townend 2002) and datasets adjusted, where

4 appropriate, using log transformations. Temperature responses were tested using

5 regression; trend lines are compared using multiple regression with temperature,

6 group identifier (e.g. water table treatment 1 or 2 referring to high and low

7 respectively), and temperature*group as independent variables. Depending on the

8 normality of the data, correlations were carried out using either Pearson's product-

9 moment or Spearman's rank correlation (Townend 2002). Where mean values are

10 quoted, the \pm value that follows refers to the standard error of the mean unless

11 otherwise stated. Analyses were carried out in 'Minitab15'.

\section{Results:}

\section{Comparison of mesocosm types/peatland features}

14 The observed differences in species composition (Fig. 2) within the mesocosms

15 was shown to be highly statistically significant using MANOVA ( $F=6.36, \mathrm{p}<$

16 0.01). All 3 mesocosm types had an average coverage of more than $60 \%$ moss.

17 The ‘Sedge/Hummock’ group was dominated by grass and moss, and also

18 contained a significant amount of the sedge E. vaginatum. The 'Hollow' group

19 was dominated primarily by mosses and the 'Juncus/Hummock' group, whilst still

20 being dominated by moss and grass, also contained an average of $40 \% \mathrm{~J}$. effusus

21 coverage. Small but significant differences were apparent in soil pH across

22 mesocosm types; ‘Juncus/Hummock’ $4.2 \pm 0.1$ (SD), 'Sedge/Hummock’ $3.9 \pm 0.1$

23 (SD), 'Hollow' $4.0 \pm 0.1$ (SD).

\section{Static water table treatment}

\section{Uptake/Emissions}

26 Mean combined plant and soil respiration across replicates during the static water

27 table portion of the study ranged from 92 to $167 \mu \mathrm{g} \mathrm{CO}_{2} \mathrm{~m}^{-2} \mathrm{~s}^{-1}$ (Table 1).

28 Respiration was highest in the 'Sedge/Hummock' group. In both the

29 'Sedge/Hummock' and 'Hollow' mesocosms, respiration was higher in the low

30 water table group; no difference was observed in the 'Juncus/Hummock' group. 
1 Although the observed patterns were not statistically significant, this was

2 expected due to the low level of replication. Light response curves were used to

3 predict photosynthesis at a PAR of $210 \mu \mathrm{mol} \mathrm{m} \mathrm{m}^{-2} \mathrm{~s}^{-1}$, the mean PAR at the

4 Auchencorth field site over the measurement period (Coyle, unpublished data).

5 Photosynthesis (Table 1) was highest in the 'Juncus/Hummock' mesocosms,

6 followed by the 'Sedge/Hummock' and finally the 'Hollow' mesocosms ( $\mathrm{F}=$

$7 \quad 5.25, \mathrm{p}<0.05)$. The effect of water table depth on photosynthesis was

8 insignificant $(\mathrm{F}=3.68, \mathrm{p}<0.10)$; however, lower water tables indicated a 44\%,

$9 \quad 36 \%$ and 21\% decrease in photosynthesis in the 'Juncus/Hummock',

10 'Sedge/Hummock' and 'Hollow' mesocosms, respectively. The resulting NEE

11 calculated from the respiration and photosynthesis data showed no significant

12 effect of either mesocosm type or water table position. However, in general the

13 lower water table treatment increased the flux of $\mathrm{CO}_{2}$ to the atmosphere (Table 1).

14 The 'Juncus/Hummock' mesocosms in the high water table treatment were the 15 only group to show a net $\mathrm{CO}_{2}$ uptake.

16 Mean $\mathrm{CH}_{4}$ fluxes from individual chambers over the 14 week period of static

17 water table treatment ranged from -30.7 to $358 \mu \mathrm{g} \mathrm{CH}_{4} \mathrm{~m}^{-2} \mathrm{~h}^{-1}$; mean $\mathrm{N}_{2} \mathrm{O}$ fluxes

18 over the same period ranged from -17.3 to $12.5 \mu \mathrm{g} \mathrm{N}_{2} \mathrm{O} \mathrm{m}^{-2} \mathrm{~h}^{-1}$. Averages across

19 chamber types and water table levels for both $\mathrm{CH}_{4}$ and $\mathrm{N}_{2} \mathrm{O}$ are presented in Table

20 1. Variation in mean $\mathrm{CH}_{4}$ flux was high within all groups, and neither water table

21 level nor mesocosm type alone had a significant effect on $\mathrm{CH}_{4}$ efflux; the effect of

22 water table was almost significant $(\mathrm{F}=3.41, \mathrm{p}<0.10)$. However, there was a

23 significant interaction effect $(\mathrm{F}=1.65, \mathrm{p}<0.05)$. Only in the high water table

24 group did mesocosm type have a significant effect on $\mathrm{CH}_{4}$ flux (Hollow >

25 Sedge/Hummock > Juncus/Hummock). A highly significant increasing trend in

26 mean $\mathrm{CH}_{4}$ flux $\left(\mathrm{r}^{2}=0.59\right.$, $\left.\mathrm{p}<0.01\right)$ was observed in the 'Sedge/Hummock' time

27 series plot (Fig. 3). When the experiment began mean $\mathrm{CH}_{4}$ emissions from the

28 'Sedge/Hummock’ mesocosms were similar in magnitude to the

29 'Juncus/Hummock’ mesocosms; however, from early April onwards the

30 'Sedge/Hummock' mesocosms were more similar to the 'Hollow' mesocosms.

31 Mean $\mathrm{CH}_{4}$ flux in all groups was positive, representing a net emission; however,

32 uptake was measured at least once throughout the experiment in all but 2 of the 33 mesocosms. 
1 There was a net uptake of $\mathrm{N}_{2} \mathrm{O}$ in 21 of the 24 mesocosms over the 14 week

2 period reflected in a net uptake across all chamber types irrespective of water

3 table (Table 1); however, variation was extremely high. No significant effect of

4 either water table depth or mesocosm type on $\mathrm{N}_{2} \mathrm{O}$ flux was observed using

5 Pillai's MANOVA test. However, using the Lawley-Hotelling (Townend 2002)

6 MANOVA post-hoc, the interaction effect was statistically significant $(F=1.72, p$

$7 \quad<0.05)$; again mesocosm type was only important in the high water table

8 treatment.

\section{$9 \quad$ Below ground concentrations}

10 Mean $\mathrm{CO}_{2}$ concentrations in the deep and shallow soil atmosphere wells were 764

$11 \pm 52$ and $680 \pm 25$ ppmv respectively; mean $\mathrm{CH}_{4}$ concentrations $127 \pm 52$ and 111

$12 \pm 37 \mathrm{ppmv}$ and mean $\mathrm{N}_{2} \mathrm{O}$ concentrations $0.38 \pm 0.01$ and $0.37 \pm 0.01 \mathrm{ppmv}$

13 (Table 2). Strong positive correlations were found between the deep and shallow

14 well concentrations for $\mathrm{CO}_{2}(\mathrm{r}=0.90, \mathrm{p}<0.01)$ and $\mathrm{N}_{2} \mathrm{O}(\mathrm{r}=0.93, \mathrm{p}<0.01)$.

15 However, no correlation was observed between $\mathrm{CH}_{4}$ concentrations in the deep

16 and shallow wells $(\mathrm{r}=-0.10, \mathrm{p}=0.80)$. Variability in the measured $\mathrm{CH}_{4}$

17 concentrations was large, ranging from below the detection limit to 5755 ppmv,

18 suggesting the presence of pockets of high $\mathrm{CH}_{4}$ concentrations within the peat

19 profile. No water table or mesocosm type effects were observed for $\mathrm{CO}_{2}$ or $\mathrm{N}_{2} \mathrm{O}$

20 concentrations (Table 2). Although not statistically significant, $\mathrm{CH}_{4}$

21 concentrations appeared to be higher in the high water table treatment. The

22 highest concentrations were observed in the 'Sedge/Hummock' mesocosms,

23 where the water table effect was also most pronounced, followed by the

24 'Hollows', and lastly the 'Juncus/Hummock' group, where no visible difference

25 was apparent between high and low water table.

26 Soil solution DOC concentrations ranged from 8.0-124 $\mathrm{mg} \mathrm{l}^{-1}$ with a mean of $43 \pm$

$272.1 \mathrm{mg} \mathrm{l}^{-1}$. Concentrations of DIC, $\mathrm{NO}_{3}{ }^{-}$and $\mathrm{NH}_{4}{ }^{+}$covered a much smaller range

28 with mean values of $3.61 \pm 0.26,0.03 \pm 0.01$ and $1.16 \pm 0.09 \mathrm{mg} \mathrm{l}^{-1}$ respectively.

29 No consistent patterns were observed across mesocosm type or water table

30 treatment in soil water solute concentrations. 
2 Both high and low water table groups showed a highly significant $\mathrm{CH}_{4}$ response

$3(\mathrm{p}<0.01)$ to natural variations in soil temperature (Fig. 4a) during the static water

4 table period. In the high water table group $\mathrm{CH}_{4}$ emissions increased with

5 increasing temperature $\left(\mathrm{r}^{2}=0.50\right)$; in the low water table group increasing

6 temperature led to a decrease in emissions $\left(r^{2}=0.26\right)$. The slopes of the 2

7 different trend lines were significantly different $(\mathrm{t}=-4.51, \mathrm{p}<0.001)$, with a

8 much stronger response to temperature in the high water table group. The $\mathrm{N}_{2} \mathrm{O}$

9 flux responded positively to increased soil temperature $\left(r^{2}=0.28\right)$ with no

10 significant difference in the trend lines between water table treatments (Fig. 4b).

11 The $\mathrm{N}_{2} \mathrm{O}$ flux showed a switch from uptake to emissions between approximately

$12 \quad 7.5$ and $8.5^{\circ} \mathrm{C}$.

13 The temperature response of $\mathrm{CH}_{4}$ in the high water table treatment group,

14 separated by mesocosm type is shown in Fig. 5. The trend lines for the

15 'Sedge/Hummock' ( $\left.\mathrm{r}^{2}=0.62, \mathrm{p}<0.01\right)$ and 'Hollow' $\left(\mathrm{r}^{2}=0.43, \mathrm{p}<0.05\right)$

16 mesocosms were offset (i.e. the 'Hollow' mesocosms had higher $\mathrm{CH}_{4}$ emissions)

17 though the slope of the lines (i.e. the response to increasing temperature) were

18 similar. The slope of the 'Juncus/Hummock' trend line was negligible and not

19 significant at $\mathrm{p}<0.05$. Mesocosm type had no significant effect on $\mathrm{CH}_{4}$ response

20 in the low water table treatment group. As variability around all trend lines was

21 great and as measurements were only made over a very limited temperature range,

22 it would be misleading to present $\mathrm{Q}_{10}$ values for the data.

\section{Response to draining/rewetting}

24 After the initial 14 week static water table treatment, the water table levels in the 2

25 treatments were switched. Over a 2 day period the high water table group was

26 drained to a new water table depth of 30-35 cm, and the low water table group

27 was wetted up until water table depth reached 0-5 cm.

28 A significant and immediate pulse, raising the $\mathrm{CH}_{4}$ flux rate to over $160 \mu \mathrm{g} \mathrm{m}^{-2} \mathrm{~h}^{-1}$

29 above what it was prior to rewetting, was observed in both the 'Hollow' and the

30 'Sedge/Hummock' mesocosms; a similar, though slightly lower pulse was

31 observed a day later in the ‘Juncus/Hummock’ mesocosms (Fig. 6a). The $\mathrm{CH}_{4}$

32 flux returned to a rate similar to its pre-change mean before rising more slowly 
1 again after approximately 8-10 days. The rate of increase in the latter stage of the

2 response was greatest in the 'Sedge/Hummock' mesocosms, followed by the

3 'Hollow' mesocosms; very little increase was observed in the 'Juncus/Hummock'

4 mesocosms. To test the significance of differences between mesocosm types, the

5 post-change period was split into 3 separate time intervals; days 0-5, 5-10 and 10-

$6 \quad$ 15. Each section was analyzed independently using a repeated measures

7 MANOVA test. The test confirmed the statistical significance of the differences in

8 mesocosm types between days $10-15$ after rewetting $(\mathrm{F}=4.00, \mathrm{p}<0.01)$.

9 A pulse of $\mathrm{CH}_{4}$, similar to that caused by rewetting was also seen in response to

10 drainage (Fig. 6c). However, the magnitude of this pulse was approximately 700

$11 \mu \mathrm{g} \mathrm{m}^{-2} \mathrm{~h}^{-1}$ above the pre-change mean in both the 'Sedge/Hummock' and the

12 'Hollow' mesocosms, and more than $200 \mu \mathrm{g} \mathrm{m}^{-2} \mathrm{~h}^{-1}$ above the pre-change mean in

13 the 'Juncus/Hummock' mesocosms; in all cases significantly higher than after

14 rewetting. After $\sim 8$ days the fluxes appeared to level off at approximately $-10,-70$

15 and $-120 \mu \mathrm{g} \mathrm{m}^{-2} \mathrm{~h}^{-1}$ below the pre-change mean in the 'Juncus/Hummock',

16 'Sedge/Hummock' and 'Hollow' mesocosms, respectively. The effect of

17 mesocosm type on response to drainage was only significant between days 5-10

$18 \quad(\mathrm{~F}=2.95, \mathrm{p}<0.05)$

19 In both the rewetting and the draining treatments, peaks in the $\mathrm{N}_{2} \mathrm{O}$ response

20 occurred after 2 days (Fig. $6 \mathrm{~b}$ and d). The pulse effect occurred only in the

21 'Hollow' mesocosms after rewetting, and in both the 'Hollow' and

22 'Juncus/Hummock’ mesocosms after draining. After the initial pulse, all

23 mesocosms, both in the rewetting and drainage treatments followed a very similar

24 pattern in terms of $\mathrm{N}_{2} \mathrm{O}$ response. This response showed no correlation with

25 temperature.

26 Solute concentrations were also collected and analysed for DOC, DIC, $\mathrm{NH}_{4}{ }^{+}$and

$27 \mathrm{NO}_{3}{ }^{-}$during both the rewetting and draining experiments. However, no significant

28 response to draining/rewetting was observed. 


\section{Discussion:}

\section{Comparison between mesocosms and field conditions}

3 Mean NEE across the different water table treatments and mesocosm types ranged

4 from -65 to $123 \mu \mathrm{g} \mathrm{CO}_{2} \mathrm{~m}^{-2} \mathrm{~s}^{-1}$ (Table 1). During the same study period, mean

5 NEE measured at the Auchencorth Moss field site using eddy covariance was -8.4

$6 \mu \mathrm{g} \mathrm{CO}_{2} \mathrm{~m}^{-2} \mathrm{~s}^{-1}$ (Coyle, unpublished data). Despite the low replication, different

7 conditions, and different measurement technique, the field site NEE is still within

8 the range measured here. Mean $\mathrm{CH}_{4}$ and $\mathrm{N}_{2} \mathrm{O}$ fluxes ranged from 0.19 to $191 \mu \mathrm{g}$

$9 \mathrm{CH}_{4} \mathrm{~m}^{-2} \mathrm{~h}^{-1}$ and from -3.4 to $-0.55 \mu \mathrm{g} \mathrm{N}_{2} \mathrm{O} \mathrm{m} \mathrm{m}^{-2} \mathrm{~h}^{-1}$ (Table 1). Fortnightly field

10 measurements over comparable vegetation types during the same period gave a

11 mean $\mathrm{CH}_{4}$ and $\mathrm{N}_{2} \mathrm{O}$ flux of $9.9 \pm 4.1 \mu \mathrm{C} \mathrm{CH}_{4} \mathrm{~m}^{-2} \mathrm{~h}^{-1}$ and $-3.3 \pm 1.5 \mu \mathrm{g} \mathrm{N}_{2} \mathrm{O} \mathrm{m}^{-2} \mathrm{~h}^{-1}$

12 (Dinsmore, unpublished data); again the field mean is within the range measured

13 in this study. Mean mesocosm DOC and $\mathrm{NH}_{4}{ }^{+}$concentrations were approximately

14 double the mean concentrations measured in the field. The higher DOC and $\mathrm{NH}_{4}{ }^{+}$

15 concentrations in the mesocosms may indicate an increase in mineralization

16 caused by the death of plant roots cut during mesocosm collection; this may also

17 explain why our mesocosms had a net $\mathrm{CO}_{2}$ emission whilst field measurements

18 over the same period showed a net uptake. DIC and $\mathrm{NO}_{3}{ }^{-}$concentrations were

19 similar between field and mesocosms. In response to a number of GHGs and

20 solutes, our mesocosms therefore appear to represent field conditions relatively

21 well.

\section{Effect of water table depth and mesocosm type}

23 Although not statistically significant our results demonstrated that under lower

24 water table conditions respiration increased and photosynthesis decreased. This is

25 consistent with similar studies (e.g. Blodau et al. 2004; Moore and Roulet 1993),

26 as water table controls the depth of the oxic peat layer, and hence the volume of

27 peat where aerobic decomposition can occur (Moore and Dalva 1993; Silvola et

28 al. 1996). However, the relationship between water table depth and respiration is

29 not linear throughout the profile with several authors reporting a breakdown in the

30 relationship below $30 \mathrm{~cm}$ (e.g. Silvola 1996; Lafleur et al. 2005). Blodau et al.

31 (2004) demonstrated a drop in photosynthesis of $24 \%$ and $42 \%$ in two different

32 Canadian peatlands, associated with a $30 \mathrm{~cm}$ drop in water level; similarly, in this 
1 study we measured a drop of between $21-44 \%$ with a similar water level change.

2 In mesocosms dominated by J. effusus and E. vaginatum, Ström et al. (2005)

3 measured mean respiration rates of $78 \mu \mathrm{g} \mathrm{m}^{-2} \mathrm{~s}^{-1}$ and $121 \mu \mathrm{g} \mathrm{m}^{-2} \mathrm{~s}^{-1}$ respectively,

4 similar to the $100 \mu \mathrm{g} \mathrm{m}^{-2} \mathrm{~s}^{-1}$ and $123 \mu \mathrm{g} \mathrm{m}^{-2} \mathrm{~s}^{-1}$ for J. effusus and E. vaginatum in

5 this study. The response of ecosystems to water table manipulations has

6 previously been shown to be dominated primarily by processes associated with

7 respiration rather than photosynthesis (Funk et al. 1994). As such, in both this

8 study and others (for example Blodau and Moore 2003a; Chimner and Cooper

9 2003; Moore and Dalva 1993), the net effect of lowered water tables is an increase

10 in $\mathrm{CO}_{2}$ flux to the atmosphere. However, despite the agreement with similar

11 studies, these results should not be directly extrapolated to predict the ecosystem

12 response to longer-term water table draw-down. Laiho (2006) highlights the

13 importance of differentiating between 'wet' and 'dry' sites. If deeper soil layers

14 are continuously exposed to aerobic decomposition, the carbon at depth becomes

15 highly recalcitrant. The associated decrease in decomposition potential is likely to

16 negate the effect of an increased aerobic zone. Several other studies have also

17 argued that in 'dry' peats, large relative changes in respiration at depth have little

18 effect on surface fluxes due to the low contribution of deeper peat to total

19 respiration (Blodau et al. 2007; Knorr et al. 2007; Lafleur et al. 2005). As the

20 natural water table regime at Auchencorth often exposes deeper layers to aerobic

21 conditions it is unsurprising that the relationship found here was small and not

22 statistically significant.

23 In accordance with previous studies (Aerts and Ludwig 1997; Moore and Dalva

24 1993), we measured higher $\mathrm{CH}_{4}$ emissions in our high water table treatment. In

25 the high water table group, the effect of mesocosm type on $\mathrm{CH}_{4}$ emissions was

26 highly significant. Based on both current literature and our photosynthesis data

27 (Table 1), we expected the order 'Juncus/Hummock' > 'Sedge/Hummock' >

28 'Hollow' due to the potential for plant-mediated transport and substrate release

29 (Greenup et al. 2000; Shannon et al. 1996; Yu et al. 1997). In this study we found

30 the opposite to be true. Emissions were lower in the 'Juncus/Hummock' and the

31 'Sedge/Hummock' mesocosms, both of which contained a large proportion of

32 aerenchyma containing plants (J. effusus, D. flexuosa and E. vaginatum). 
1 As well as providing a transport route for $\mathrm{CH}_{4}$, aerenchyma also transports $\mathrm{O}_{2}$ into

2 the rhizosphere and can significantly alter the redox state of saturated peat,

3 resulting in decreased methanogenesis and increased oxidation (Visser et al. 2000;

4 Wiebner et al. 2002). Lombardi et al. (1997) measured $\mathrm{CH}_{4}$ oxidation potentials

5 of $44-318 \mathrm{mg} \mathrm{m}^{-2} \mathrm{~d}^{-1}$ in the rhizosphere of common aerenchymous wetland

6 species. The amount of radial oxygen loss through the plant roots is likely to be

7 dependent on photosynthetic activity (Roura-Carol and Freeman 1999). In the low

8 water table treatment group, due to the limited depth of our mesocosms, only a

9 very shallow anoxic layer for methanogenesis is likely to have existed. The

10 absence of a significant $\mathrm{CH}_{4}$ reservoir for plant roots to tap into may have

11 restricted the potential for plant-mediated transport. Although the majority of

12 studies have found a positive effect of vascular plants on $\mathrm{CH}_{4}$ emissions, a few

13 have reported results similar to this study, where emission inhibition by

14 rhizospheric oxidation appears to be greater than the increase in emissions via

15 plant-mediated transport and enhanced substrate release (Grünfeld and Brix 1999;

16 Kutzbach et al. 2004). Similarly Arah and Stephen (1998) found that increasing

17 the root-mediated transport potential in a $\mathrm{CH}_{4}$ flux model resulted in decreased net

18 emissions due to the increase in oxidation outweighing increased $\mathrm{CH}_{4}$ transport.

19 The increase in $\mathrm{CH}_{4}$ emissions from the 'Sedge/Hummock' mesocosms

20 throughout the study period (Fig. 3) may indicate a seasonal shift in the balance of

21 positive and negative effects of vascular plants on $\mathrm{CH}_{4}$ emissions. The conduit

22 potential of aerenchyma containing plants is likely to increase seasonally due to

23 the relationship between root biomass and stem cross-sectional area (Arenovski

24 and Howes 1992; Waddington et al. 1996). The production of deep roots reaching

25 the anoxic peat layer (Wein 1973), or increased substrate release early in the

26 growing season (Saarnio et al. 2004), may also cause seasonal changes in plant-

27 related emissions. The earlier initiation of E. vaginatum growth than Juncus

28 effusus (Wein 1973) may explain why a similar increasing trend is not observed in

29 the 'Juncus/Hummock' mesocosms. Longer-term measurements are needed to test

30 this hypothesis.

31 The pattern of below ground $\mathrm{CH}_{4}$ concentrations ('Sedge/Hummock' > 'Hollow')

32 was opposite to that seen in surface emissions ('Hollow' > 'Sedge/Hummock').

33 This suggests that although more $\mathrm{CH}_{4}$ is produced in the 'Sedge/Hummock' 
mesocosms, there is a barrier preventing soil-atmosphere transfer. This could be

2 either oxidation in the rhizosphere (assuming soil atmosphere wells did not

3 sample the rhizosphere), or a physical barrier such as the thick layer of hummock

4 biomass preventing diffusion across the soil-atmosphere boundary. As bubble

5 formation does not occur until partial pressures of $>0.21$ atm (Fechner-Levy and

6 Hemond 1996), this is unlikely to be important in our mesocosms. The extremely

7 high variability in soil-atmosphere $\mathrm{CH}_{4}$ concentrations and the lack of correlation

8 between shallow and deep wells may indicate spatial heterogeneity in rates of

9 production and oxidation within the soil profile caused by plant roots. High

10 concentrations in the Sedge/Hummock mesocosms may also be due to substrate

11 availability. E. vaginatum has previously been shown to release much higher

12 quantities of acetate, a substrate of major importance to $\mathrm{CH}_{4}$ production, than $J$.

13 effusus (Ström et al. 2005).

14 Relatively few conclusions can be drawn from the pattern of $\mathrm{N}_{2} \mathrm{O}$ fluxes and

15 concentrations due to the very high temporal variability. Low $\mathrm{NO}_{3}{ }^{-}$concentrations

16 in soil water may indicate low nitrification rates. An increased rate of nitrification

17 has been observed after water-table drawdown in several studies (Neill 1995;

18 Regina et al. 1996). Similarly in this study, although not significant,

19 concentrations of $\mathrm{NO}_{3}{ }^{-}$were higher in the low water table treatment in both

20 'Sedge/Hummock' and 'Hollow' mesocosms. Alternatively, the low $\mathrm{NO}_{3}{ }^{-}$pool

21 may be a consequence of high turnover rates. $\mathrm{N}_{2} \mathrm{O}$ consumption from complete

22 denitrification may be the dominant process controlling $\mathrm{N}_{2} \mathrm{O}$ fluxes to and from

23 this system.

\section{Temperature response}

25 The clear difference in the temperature response of $\mathrm{CH}_{4}$ emissions between the

26 high and low water table groups (Fig. 4) was likely a result of different processes

27 contributing to the net flux. In anoxic (high water table) conditions the dominant

28 process was methanogenesis which increases emissions as microbial activity

29 increases in response to increasing temperature. This is in agreement with

30 previous studies which show a stronger temperature response in methanogenesis

31 than methanotrophy (Dunfield et al. 1993). In oxic (low water table) conditions

32 methanotrophy as well as methanogenesis contributed to the net flux, dampening

33 the overall response. The responses of both the 'Hollow' and the 
1 'Sedge/Hummock' mesocosms were similar, suggesting a common dominant

2 process (methanogenesis). The 'Juncus/Hummock' however, more closely

3 resembled the response of the low water table group, indicating that

4 methanotrophy was also important. This supports the assertion that rhizospheric

5 oxidation was important in the 'Juncus/Hummock' mesocosms. The temperature

6 responses here appeared to be linear compared to the exponential responses

7 observed in other studies (Dise et al. 1993; MacDonald et al. 1998). However,

8 this may simply be a consequence of the limited range of temperatures our

9 mesocosms were exposed to.

10 We found a positive linear response of $\mathrm{N}_{2} \mathrm{O}$ emissions to temperature with a

11 switch from consumption to production between approximately 7.5 and $8.5^{\circ} \mathrm{C}$.

12 This suggests that $\mathrm{N}_{2} \mathrm{O}$ producing processes are more responsive to temperature

13 than $\mathrm{N}_{2} \mathrm{O}$ consumption processes. Water table position had no effect on the

14 magnitude of the $\mathrm{N}_{2} \mathrm{O}$ temperature response. Further work is required to assess the

15 validity of the observed switch from consumption to production as $\mathrm{N}_{2} \mathrm{O}$ fluxes in

16 this study are low and variability high.

\section{Pulsing effect}

18 After switching water table positions, both drainage and rewetting produced

19 evidence of a significant pulse in $\mathrm{CH}_{4}$ and $\mathrm{N}_{2} \mathrm{O}$ emissions within 1 or 2 days. This

20 pulse may be the direct result of the physical disturbance (water table shift)

21 causing a release of $\mathrm{CH}_{4}$ and $\mathrm{N}_{2} \mathrm{O}$ from below ground reservoirs. Episodic pulsing

22 after water table drawdown was seen by both Moore et al. (1990) and Shurpali et

23 al. (1993) and was attributed to degassing due to reduced hydrostatic pressure.

24 Alternatively, pulses may be a biological response to increased substrate

25 availability from enhanced biomass recycling or redox-induced chemical

26 breakdown (Blodau and Moore 2003b). Similar pulses in mineralization rates

27 have been observed in response to water level fluctuations (Aerts and Ludwig

28 1997). After the initial pulse, the $\mathrm{CH}_{4}$ response to drainage occurred faster than

29 the response to rewetting. This is consistent with previous studies (Whalen and

30 Reeburgh 2000). $\mathrm{N}_{2} \mathrm{O}$ fluxes were similar across all mesocosm types and water

31 table positions. 
2 From continuous water table measurements made at the Auchencorth Moss

3 peatland in 2007 (Coyle, unpublished data), a rise in water table by more than 20

$4 \mathrm{~cm}$ in less than 48 hours occurred 9 times in 8 months. Assuming emissions in

5 both $\mathrm{CH}_{4}$ and $\mathrm{N}_{2} \mathrm{O}$ peak each time this occurs and the peak lasts approximately 24

6 hours, fortnightly field measurements may fail to capture these peaks. The results

7 from the mesocosm study suggest that $\mathrm{CH}_{4}$ pulsing after rewetting could

8 potentially contribute an additional $16 \%$ to the average annual flux. Using the

9 same assumptions, net $\mathrm{N}_{2} \mathrm{O}$ flux could switch from a net sink of 0.008 to a net

10 source of $0.02 \mu \mathrm{g} \mathrm{m}^{-2} \mathrm{~h}^{-1}$ (Dinsmore et al., unpublished data, 2008). Although this

11 is only a rough calculation and the assumptions are large, it illustrates the

12 potential importance of these emission pulses after a sudden rise in field water

13 table levels. No such calculation was carried out on the pulses observed after

14 drainage as it is extremely unlikely that a water table drop of this magnitude

15 would occur over only 2 days in the field. Further work is required to assess the

16 actual implications of this pulsing under natural field conditions.

17 Using the 100 year global warming potentials published by the IPCC (2007), the

18 GHG fluxes in $\mathrm{CO}_{2}$ equivalents for each group of mesocosms was calculated

19 (Table 3). In this system, $\mathrm{CO}_{2}$ fluxes dominate the budget entirely. $\mathrm{CH}_{4}$ fluxes are

20 an order of magnitude smaller than in many studies (e.g. Dowrick et al. 2006;

21 Hargreaves and Fowler 1998; Minkkinen et al. 2002; Minkkinen and Laine 2006;

22 Roulet et al. 2007), though studies such as MacDonald et al (1998) found similar

23 values in Scottish blanket peats. Fluxes of $\mathrm{CO}_{2}$-equivalents from $\mathrm{N}_{2} \mathrm{O}$ are in the

24 same order of magnitude as $\mathrm{CO}_{2}$-equivalents from $\mathrm{CH}_{4}$. Lowering the water table

25 by $30 \mathrm{~cm}$ greatly increased the net flux of $\mathrm{CO}_{2}$-equivalents to the atmosphere,

26 which was dominated by NEE. Of the different mesocosm types, only the $J$.

27 effusus dominated hummocks show a net uptake of $\mathrm{CO}_{2}$-equivalents. Hence it is

28 important to accurately account for the relative proportions of each community

29 type when up-scaling chamber measurements made in the field.

30 Conclusions:

31 Our results agree with previous studies on the flux responses to low water table

32 conditions. We have also demonstrated the strong interaction between water table 
1 depth and vegetation. The effect of vegetation within the mesocosms was counter

2 to what we had originally hypothesised based on the available literature. What

3 determines the ratio between flux enhancing and flux inhibiting mechanisms in

4 plant communities is still largely unclear and may be related to both site-specific

5 and species-specific variables, which may change seasonally with plant growth

6 stage. Despite the uncertainty in the mechanisms involved, it is clear that species

7 composition has a dramatic effect on ecosystem functioning, and as such it is

8 important that community type is considered when up-scaling chamber

9 measurements. It also highlights the need to include some form of vegetation

10 succession in models used to predict long-term effects of landscape management

11 and environmental change on GHG budgets.

12 We observed a pulse in both $\mathrm{CH}_{4}$ and $\mathrm{N}_{2} \mathrm{O}$ emissions occurring between 1-2 days

13 after manually changing the depth of the water table by $\pm 30 \mathrm{~cm}$. Though further

14 work is required to quantify the importance of this pulse under field conditions, it

15 can be concluded that low frequency chamber measurements may significantly

16 underestimate mean annual emissions.

\section{Acknowledgements}

18 We thank Frank Harvey and the staff at CEH Edinburgh for their help and advice throughout the

19 study, and John Parker (Scottish Agricultural College) for his help with laboratory work. The work

20 was funded by the UK Natural Environment Research Council (NERC) through an algorithm PhD

21 studentship grant.

\section{References}

24 Arah J R M and Stephen K D (1998) A model of the processes leading to methane emission from

25 peatland. Atmos Environ 32:3257-3264

26 Aerts R and Ludwig F (1997) Water-table changes and nutritional status affect trace gas emissions

27 from laboratory columns of peatland soils. Soil Biol Biochem 29:1691-1698

28 Arenovski A L and Howes B L (1992) Lacunal allocation and gas transport capacity in the salt

29 marsh grass Spartina alterniflora. Oecologia 90:316-322

30 Bartlett K B and Harriss R C (1993) Review and Assessment of Methane Emissions from

31 Wetlands. Chemosphere 26:261-320

32 Billett M F, Palmer SM, Hope D, Deacon C, Storeton-West R, Hargreaves KJ, Flechard C and

33 Fowler D (2004) Linking land-atmosphere-stream carbon fluxes in a lowland peatland system,

34 Global Biogeochem Cycles 18: GB1024, doi:10.1029/2003GB002058.

35 Blodau C, Basiliko N and Moore T R (2004) Carbon turnover in peatland mesocosms exposed to

36 different water table levels. Biogeochemistry 67:331-351

37 Blodau C and Moore T R (2003a) Experimental response of peatland carbon dynamics to a water

38 table fluctuation. Aquat Sci 65:47-62 
Blodau C and Moore T R (2003b) Micro-scale $\mathrm{CO}_{2}$ and $\mathrm{CH}_{4}$ dynamics in a peat soil during a water table fluctuation and sulphate pulse. Soil Biol Biochem 35:535-547

Blodau C, Roulet N T, Heitmann, T, Stewart H, Beer J, Lafleur P and Moore T R (2007)

Belowground carbon turnover in a temperate ombrotrophic bog. Global Biogeochem Cycles 21:GB1021

6 Butterbach-Bahl K, Papen H and Rennenberg H (1997) Impact of gas transport through rice cultivars on methane emission from rice paddy fields. Plant Cell Environ 20:1175-1183

8 Chimner R A and Cooper D J (2003) Influence of water table levels on $\mathrm{CO}_{2}$ emissions in a

9 Colorado subalpine fen: an in situ microcosm study. Soil Biol Biochem 35:345-351

10 Dawson J J C, Billett M F, Hope D, Palmer S M and Deacon C M (2004), Sources and sinks of 11 aquatic carbon in a peatland stream continuum, Biogeochemistry 70: 71-92

12 Dise N B, Gorham E and Verry E S (1993) Environmental-Factors Controlling Methane Emissions from Peatlands in Northern Minnesota. J Geophys Res [Atmos] 98:10583-10594

14 Dowrick D J, Freeman C, Lock M A and Reynolds B (2006) Sulphate reduction and the 15 suppression of peatland methane emissions following summer drought. Geoderma 132:384-390 Dunfield P, Knowles R, Dumont R and Moore T R (1993) Methane production and consumption in temperate and subarctic peat soils: Response to temperature and pH. Soil Biochemistry 25:32118326

Frolking S, Roulet N T, Moore T R, Lafleur J L, Bubier J L and Crill P M (2002) Modeling seasonal to annual carbon balance of Mer Bleue Bog, Ontario, Canada. Global Biogeochem Cycles 16:GB1030

Funk D W, Pullman E R, Peterson K M, Crill P M and Billings W D (1994) Influence of WaterTable on Carbon-Dioxide, Carbon-Monoxide, and Methane Fluxes from Taiga Bog Microcosms. Global Biogeochem Cy 8:271-278

Gorham E (1991) Northern Peatlands: Role in the Carbon-Cycle and Probable Responses to 26 Climatic Warming. Ecol Appl 1:182-195

Greenup A L, Bradford M A, McNamara N P, Ineson P and Lee J A (2000) The role of Eriophorum vaginatum in $\mathrm{CH}_{4}$ flux from an ombrotrophic peatland. Plant Soil 227:265-272

29 Grünfeld S and Brix H (1999) Methanogenesis and methane emissions: effects of water table, 30 substrate and presence of Phragmites australis. Aquat Bot 64:63-75

31 Gut A, Blatter A, Fahrni M, Lehmann B E, Neftel A and Staffelbach T (1998) A new membrane tube technique (METT) for continuous gas measurements in soils. Plant Soil 198:79-88 Hargreaves K J and Fowler D (1998) Quantifying the effects of water table and soil temperature on the emission of methane from peat wetland at the field scale. Atmos Environ 32:3275-3282

Huttunen J T, Nykanen H, Turunen J and Martikainen P J (2003) Methane emissions from natural peatlands in the northern boreal zone in Finland, Fennoscandia. Atmos Environ 37:147-151

IPCC (2007) Technical Summary. In Climate Change (2007): The Physical Science Basis. Contribution of Working Group 1 to the Forth Assessment Report of the Intergovernmental Panel on Climate Change. Eds. S Solomon, D Qin, M Manning, Z Chen, M Marquis, K B Averyt, M NY, USA

Knorr K -H, Osterwoud M and Blodau C (2007) Experimental drought changes rates of soil 1791

Kutzbach L, Wagner D and Pfeiffer E M (2004) Effect of microrelief and vegetation on methane emission from wet polygonal tundra, Lena Delta, Northern Siberia. Biogeochemistry 69:341-362

Lafleur P M, Moore T R, Roulet N T and Frolking S (2005) Ecosystem respiration in a cool temperate bog depends on peat temperature but not water table. Ecosystems 8:619-629

49 Laiho (2006) Decomposition in peatlands: reconciling seemingly contrasting results on the 50 impacts of lowered water levels. Soil Biol Biochem 38:2011-2024

51 Lombardi J E, Epp M A and Chanton J P (1997) Investigation of the methyl fluoride technique for 52 determining rhizospheric methane oxidation. Biogeochemistry 36:153-172 
1 MacDonald J A, Fowler D, Hargreaves K J, Skiba U, Leith I D and Murray M B (1998) Methane emission rates from a northern wetland; response to temperature, water table and transport. Atmos Environ 32:3219-3227

4 Minkkinen K, Korhonen R, Savolainen I and Laine J (2002) Carbon balance and radiative forcing of Finnish peatlands 1900-2100 - the impact of forestry drainage. Glob Change Biol 8:785-799

Minkkinen K and Laine J (2006) Vegetation heterogeneity and ditches create spatial variability in methane fluxes from peatlands drained for forestry. Plant Soil 285:289-304

8 Moore T R and Dalva M (1993) The influence of temperature and water table on carbon dioxide 9 and methane emissions from laboratory columns of peatland soils. J Soil Sci 44:651-664

10 Moore T R and Roulet N T (1993) Methane Flux - Water-Table Relations in Northern Wetlands.

11 Geophys Res Lett 20:587-590

12 Moore T R, Roulet N T and Knowles R (1990) Spatial and temporal variations of methane flux 13 from subarctic/northern boreal fens. Glob Biogeochem Cycles 4:29-46

14 Neill C (1995) Seasonal flooding, nitrogen mineralization and nitrogen utilization in a prairie 15 marsh. Biogeochemistry 30:171-189

16 Nungesser M K (2003) Modelling microtopography in boreal peatlands: hummocks and hollows.

17 Ecol Model 165:175-207

18 Öquist M and Sundh I (1998) Effects of a transient oxic period on mineralization of organic matter 19 to $\mathrm{CH}_{4}$ and $\mathrm{CO}_{2}$ in anoxic incubations. Geomicrobiol J 15:325-333

20 Regina K, Nykanen H, Silvola J and Martikainen P J (1996) Fluxes of nitrous oxide from boreal peatlands as affected by peatland type, water table level and nitrification capacity. Biogeochemistry 35:401-418

23 Regina K, Silvola J and Martikainen P J (1999) Short-term effects of changing water table on $\mathrm{N}_{2} \mathrm{O}$ 24 fluxes from peat monoliths from natural and drained boreal peatlands. Glob Change Biol 5:18325189

26 Roulet N, Lafleur P M, Richard P J H, Moore T R, Humphreys E R and Bubier J (2007)

27 Contemporary carbon balance and late Holocene carbon accumulation in a northern peatland. Glob 28 Change Biol 13:397-411

29 Roura-Carol M and Freeman C (1999) Methane release from peat soils: effects of Spagnum and 30 Juncus. Soil Biol Biochem 31:323-325

31 Saarnio S, Wittenmayer L and Merbach W (2004) Rhizospheric exudation of Eriophorum 32 vaginatum L. - Potential link to methanogenesis. Plant Soil 267:343-355

33 Shannon R D, White J R, Lawson J E and Gilmour B S (1996) Methane efflux from emergent 34 vegetation in peatlands. J Ecol 84:239-246

35 Shurpali N J, Verma S B, Clement R J and Billesbach D P (1993) Seasonal distribution of methane 36 flux in a Minnesota peatland measured by eddy-correlation. J Geophys Res [Atmos] 98:206493720655

38 Silvola J, Alm J, Ahlholm U, Nykänen H and Martikainen P J (1996) CO2 fluxes from peat in 39 boreal mires under varying temperature and moisture conditions. J Ecol 84:219-228

40 Strack M, Waller M F and Waddington J M (2006) Sedge succession and peatland methane 41 dynamics: a potential feedback to climate change. Ecosystems 9:278-287

42 Ström L, Ekberg A, Mastepanov M and Christensen T R (2003) The effect of vascular plants on 43 carbon turnover and methane emissions from a tundra wetland. Glob Change Biol 9:1185-1192

44 Ström L, Mastepanov M and Christensen T R (2005) Species-specific Effects of Vascular Plants on Carbon Turnover and Methane Emissions from Wetlands. Biogeochemistry 75:65-82

46 Townend J (2002) Practical statistics for environmental and biological scientists. John Wiley \& 47 Sons Ltd, Chicester

48 Updegraff K, Bridgham S D, Pastor J, Weishampel P and Harth C (2001) Response of $\mathrm{CO}_{2}$ and $49 \mathrm{CH}_{4}$ emissions from peatlands to warming and water table manipulation. Ecol Appl 11:311-326

50 Urban N R, Bayley S E and Eisenreich S J (1989) Export of dissolved organic carbon and acidity 51 from peatlands. Water Resour Res 25:1619-1628 
1 Visser E J, Colmer T D, Blom C W P M and Voesenek L A C J (2000) Changes in growth, porosity, and radial oxygen loss from adventitious roots of selected mono- and dicotyledonous wetland species with contrasting types of aerenchyma. Plant Cell Environ 23:1237-1245

4 Waddington J M, Roulet N T and Swanson R V (1996) Water table control of CH4 emission 5 enhancement by vascular plants in boreal peatlands. J Geophys Res [Atmos] 101:22775-22785

6 Wein R W (1973) Eriophorum Vaginatum L. J Ecol 61:601-615

7 Weltzin J F, Bridgham S D, Pastor J, Chen J and Harth C (2003) Potential effects of warming and

8 drying on peatland plant communty composition. Glob Change Biol 9:141-151

9 Whalen S C and Reeburgh W S (2000) Methane oxidation, production, and emission at contrasting 10 sites in a boreal bog. Geomicrobiol J 17:237-251

11 Whiting G J and Chanton J P (1996) Control of Diurnal pattern of methane emission from aquatic 12 macrophytes by gas transport mechanisms. Aquat Bot 54:237-253

13 Wiebner A, Kuschk P and Stottmeister U (2002) Oxygen release by roots of Typha latifolia and 14 Juncus effusus in laboratory hydroponic systems. Acta Biotechnol 22:209-216

15 Yavitt J B, Williams C J and Wieder R K (1997) Production of methane and carbon dioxide in 16 peatland ecosystems across North America: Effects of temperature, aeration, and organic 17 chemistry of the peat. Geomicrobiol J 14:299-316

18 Yu K W, Wang Z P and Chen G X (1997) Nitrous oxide and methane transport through rice 19 plants. Biol Fert Soils 24:341-343 


\section{Figure Legends}

2 Fig. 1 Illustration of mesocosm design. Note diagram is not to scale

3 Fig. 2 Vegetation composition within different mesocosm types. Error bars represent standard 4 deviations. Rush refers only to J. effusus and sedge to Eriophorum vaginatum. The grass was 5 predominantly Deschamsia flexuosa; Agrostis stolonifera, Anthoxanthum odoratum, Festuca 6 ovina, and Molinia caerulea are also present in some mesocosms. The dominant mosses are 7 Sphagnum papillosa and Polytrichum commune. The herb species present were Potentilla erecta 8 and Galium saxatile

9 Fig. 3 Time series of mean $\mathrm{CH}_{4}$ emissions in high water table group during static water table 10 treatment

11 Fig. 4 (a) $\mathrm{CH}_{4}$ and (b) $\mathrm{N}_{2} \mathrm{O}$ flux response to temperature in high and low water table treatment 12 groups

13 Fig. $5 \mathrm{CH}_{4}$ flux response to temperature in high water table treatment separated by mesocosm type

14 Fig. 6 Change in flux relative to mean prior to water table switch; a) and b) illustrate response to 15 rewetting, c) and d) illustrate response to draining. Positive values represent an increase from pre16 change mean; negative values indicate a decrease in flux rate from the pre-change mean 


\section{Tables}

3 Table 1 Mean ( \pm SE) fluxes of $\mathrm{CO}_{2}, \mathrm{CH}_{4}$ and $\mathrm{N}_{2} \mathrm{O}$ separated by water table depth and 4 mesocosm type. Values of $\mathrm{CO}_{2}$ are based on 2 sampling occasions; values for $\mathrm{CH}_{4}$ and $\mathrm{N}_{2} \mathrm{O}$ 5 represent weekly fluxes the full 14 week static water table treatment. Note different units for $6 \mathbf{C O}_{2}$.

\begin{tabular}{lcccccc}
\hline & \multicolumn{2}{c}{ Juncus/Hummock } & \multicolumn{2}{c}{ Sedge/Hummock } & \multicolumn{2}{c}{ Hollow } \\
& High & Low & High & Low & High & Low \\
\hline $\mathrm{CO}_{2}\left(\mu \mathrm{g} \mathrm{m}^{-2} \mathrm{~s}^{-1}\right)$ & & & & & \\
Respiration & $101 \pm 12$ & $102 \pm 7.6$ & $124 \pm 10$ & $167 \pm 26$ & $92 \pm 7.1$ & $105 \pm 5.8$ \\
Photosynthesis & $165 \pm 75$ & $92 \pm 25$ & $69 \pm 24$ & $44 \pm 10$ & $45 \pm 13$ & $36 \pm 3.8$ \\
$\mathrm{NEE}$ & $-65 \pm 53$ & $9.1 \pm 11$ & $55 \pm 22$ & $123 \pm 19$ & $58 \pm 12$ & $70 \pm 3.8$ \\
$\mathrm{CH}_{4}\left(\mu \mathrm{g} \mathrm{m}^{-2} \mathrm{~h}^{-1}\right)$ & $11 \pm 5.2$ & $0.19 \pm 5.2$ & $117 \pm 28$ & $3.2 \pm 3.4$ & $191 \pm 27$ & $5.8 \pm 4.9$ \\
$\mathrm{~N}_{2} \mathrm{O}\left(\mu \mathrm{g} \mathrm{m}^{-2} \mathrm{~h}^{-1}\right)$ & $-3.2 \pm 2.2$ & $-0.82 \pm 2.1$ & $-3.4 \pm 2.1$ & $-1.8 \pm 1.7$ & $-0.55 \pm 1.5$ & $-0.85 \pm 2.0$ \\
7 & & & & & &
\end{tabular}


2 Table 2 Mean ( $\pm \mathrm{SE}$ ) concentrations of $\mathrm{CO}_{2}, \mathrm{CH}_{4}$ and $\mathrm{N}_{2} \mathrm{O}$ in soil atmosphere wells during 3 static water table treatment. Units are ppmv

\begin{tabular}{|c|c|c|c|c|c|c|}
\hline & \multicolumn{2}{|c|}{ Juncus/Hummock } & \multicolumn{2}{|c|}{ Sedge/Hummock } & \multicolumn{2}{|c|}{ Hollow } \\
\hline & High & Low & High & Low & High & Low \\
\hline \multicolumn{7}{|l|}{$\mathrm{CO}_{2}$} \\
\hline Shallow & $694 \pm 88$ & $722 \pm 63$ & $711 \pm 71$ & $687 \pm 80$ & $574 \pm 63$ & $695 \pm 74$ \\
\hline Deep & $739 \pm 89$ & $924 \pm 203$ & $726 \pm 105$ & $756 \pm 102$ & $801 \pm 160$ & $639 \pm 60$ \\
\hline \multicolumn{7}{|l|}{$\mathrm{CH}_{4}$} \\
\hline Shallow & $19 \pm 8.2$ & $7.1 \pm 2.6$ & $484 \pm 173$ & $88 \pm 77$ & $39 \pm 14$ & $29 \pm 13$ \\
\hline Deep & $19 \pm 4.1$ & $28 \pm 8.2$ & $222 \pm 148$ & $42 \pm 24$ & $433 \pm 148$ & $17 \pm 9.3$ \\
\hline \multicolumn{7}{|l|}{$\mathrm{N}_{2} \mathrm{O}$} \\
\hline Shallow & $0.39 \pm 0.02$ & $0.42 \pm 0.03$ & $0.37 \pm 0.02$ & $0.38 \pm 0.01$ & $0.31 \pm 0.01$ & $0.37 \pm 0.01$ \\
\hline $\begin{array}{l}\text { Deep } \\
4\end{array}$ & $0.44 \pm 0.04$ & $0.41 \pm 0.04$ & $0.37 \pm 0.01$ & $0.38 \pm 0.01$ & $0.31 \pm 0.01$ & $0.39 \pm 0.01$ \\
\hline
\end{tabular}


2 Table $3 \mathrm{GHG}$ fluxes from mesocosms using $100 \mathrm{yr}$ global warming potentials of 298 for $\mathrm{N}_{2} \mathrm{O}$

3 and 25 for $\mathrm{CH}_{4}$ (IPCC 2007). Flux units are $\mathrm{mg} \mathrm{CO}_{2}-\mathrm{eq} \mathrm{m}^{-2} \mathrm{~d}^{-1} \pm \mathrm{SE}$; positive and negative

4 values represent emissions and uptake respectively

\begin{tabular}{lccccc}
\hline & Water table & $\mathrm{CO}_{2}$ & $\mathrm{CH}_{4}$ & $\mathrm{~N}_{2} \mathrm{O}$ & $\mathrm{Net} \mathrm{CO}_{2}$-eq \\
\hline \multirow{3}{*}{ Juncus/Hummock } & High & $-5592 \pm 3264$ & $6.7 \pm 5.5$ & $-23 \pm 29$ & -5608 \\
& Low & $792 \pm 936$ & $6.2 \pm 5.8$ & $-6.0 \pm 27$ & 792 \\
\multirow{3}{*}{ Sedge/Hummock } & High & $4776 \pm 1656$ & $70 \pm 30$ & $-25 \pm 26$ & 4822 \\
& Low & $10608 \pm 1176$ & $1.9 \pm 3.6$ & $-13 \pm 22$ & 10597 \\
Hollow & High & $4008 \pm 912$ & $115 \pm 29$ & $-4.1 \pm 19$ & 4119 \\
& Low & $6024 \pm 288$ & $3.4 \pm 5.3$ & $-6.0 \pm 25$ & 6021
\end{tabular}





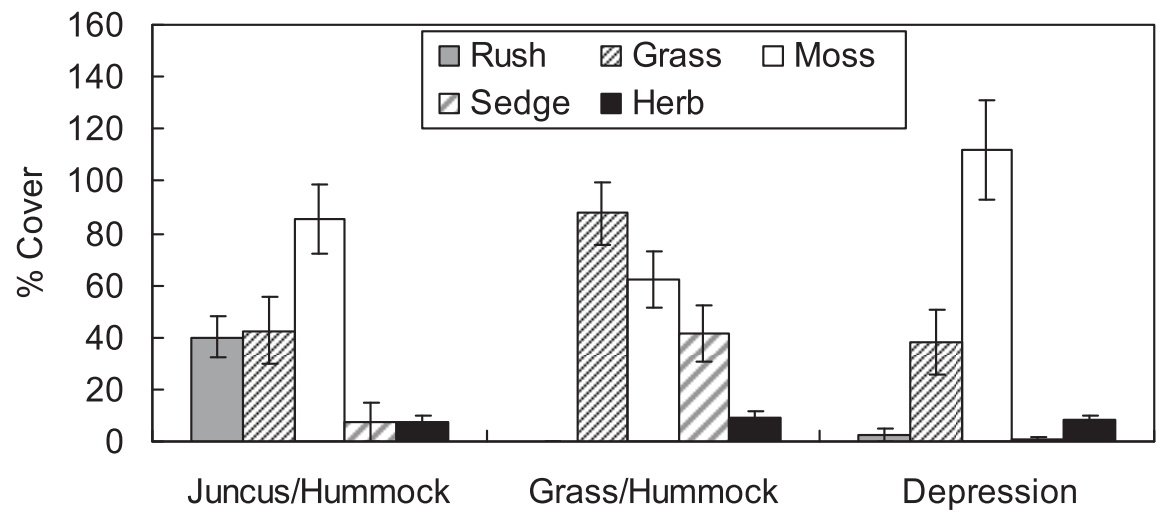




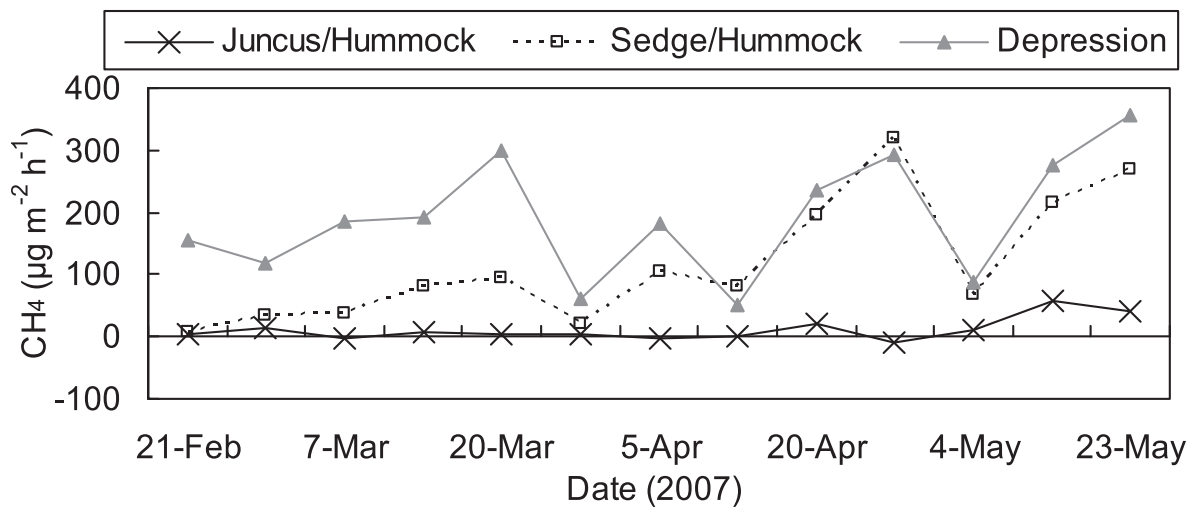



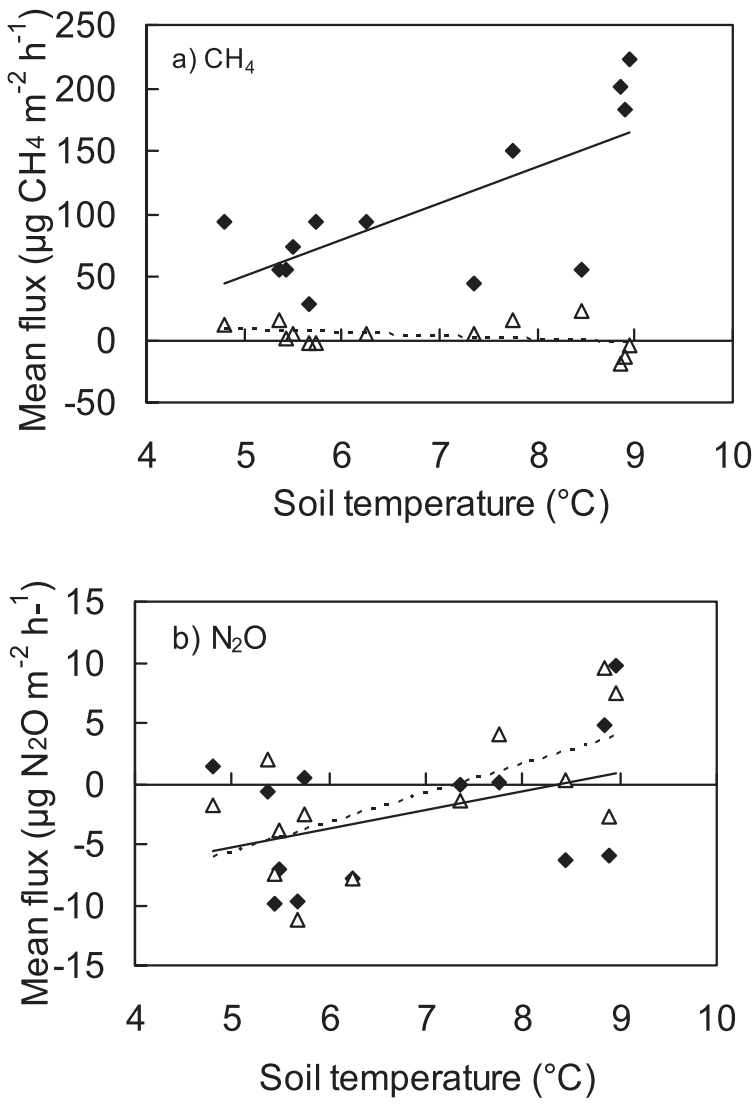
High $\quad \cdots-\Delta^{---}$Low 


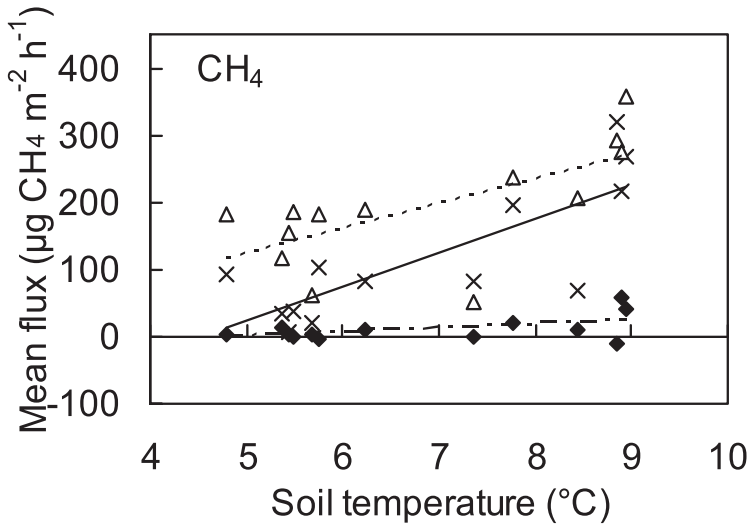

$$
\begin{array}{cl}
\cdots \cdots & \text { Juncus/Hummock } \\
\hdashline-\cdots & \text { Sedge/Hummock } \\
\hdashline-\triangle & \text { Depression }
\end{array}
$$



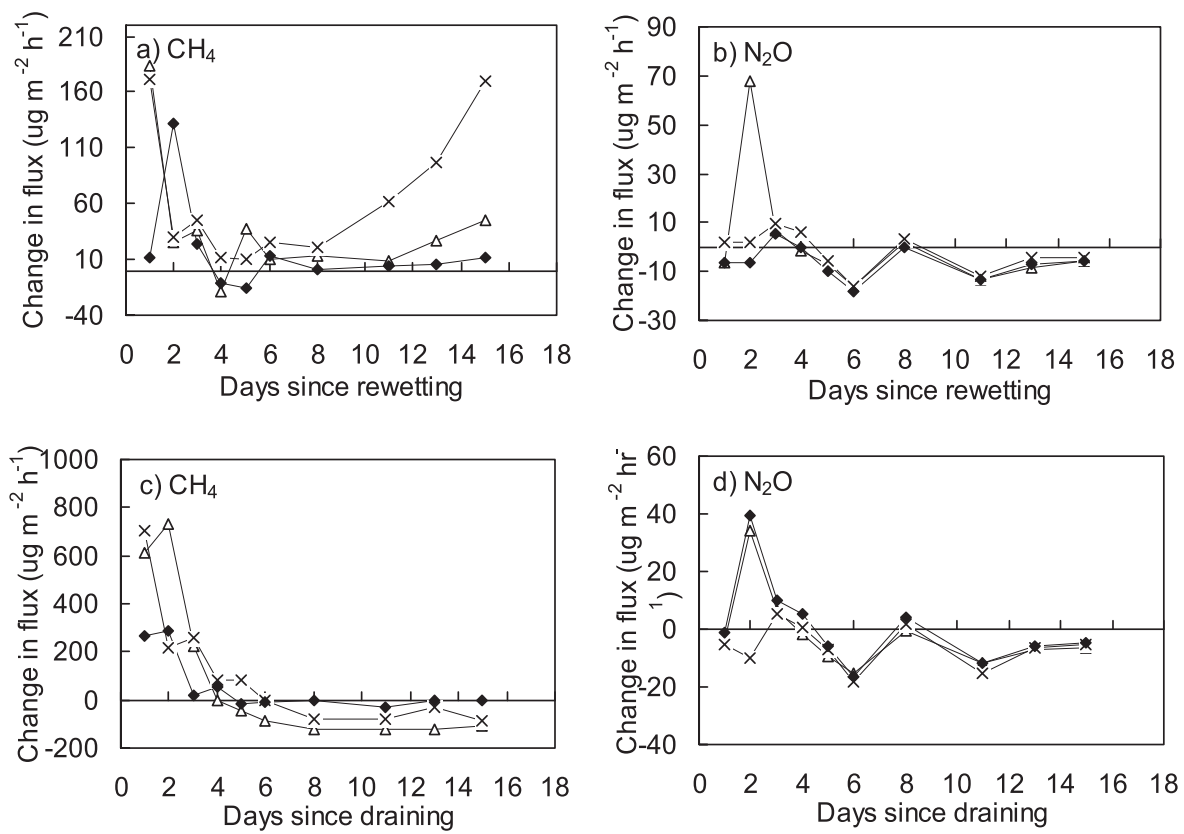

$\longrightarrow$ Juncus/Hummock $\longrightarrow x \quad$ Sedge/Hummock $\longrightarrow \Delta$ Depression 